\title{
Profilointia yhteistyönä?
}

S uomalaisen korkeakoulu- ja tiedepolitiikan ydinteemoja on viimeisen 15 vuoden ollut keskustelu rakenteellisesta kehittämisestä ja profiloitumisesta. Rakenteellisen kehittämisen osana korkeakouluja on fuusioitu aktiivisesti: yliopistojen lukumäärä on reilussa 10 vuodessa vähentynyt seitsemällä ja ammattikorkeakoulujen kuudella. Korkeakoulujen ja erityisesti yliopistojen alakohtaista profiloitumista sen sijaan ei ole saatu edistettyä kovasta yrityksestä huolimatta. Itse profiloitumisen käsite myös tuntuu elävän käyttäjän ja kontekstin mukaisesti. Yleisesti kuitenkin profilointi terminä liitetään vahvuusalueiden ja -alojen tunnistamiseen ja niihin panostamiseen. Tällöin profiloituminen saattaa sisältää ajatuksen myös "poisvalinnoista", eli toimintojen tai alojen lakkauttamisesta tai siirtämisestä toiseen korkeakouluun.

Vuosina 2014-2015 Suomen yliopistojen rehtorineuvosto (Unifi) koordinoi useiden alojen rakenteellisen kehittämisen hankkeita. Hankkeiden taustalla oli ajatus siitä, että yliopistolakiuudistuksen korostama autonomia mahdollistaisi yliopistojen omaehtoisen työnjaon kehittämisen. Lisäksi yliopistojen keskinäisen profiloitumisen uskottiin olevan ministeriöohjausta kestävämpi ja hyväksyttävämpi tapa edetä. Myös yhteiskuntatieteellisellä alalla profiloitumista yritettiin edistää mainittujen kehittämishankkeiden puitteissa. Vuonna 2015 julkaistussa "Yhteiskuntatieteellisen alan koulutuksen ja tutkimuksen rakenteellinen kehittäminen ja profilointi" -raportissa esitettiin alaan liittyvien päällekkäisyyksien purkamista. Purkaminen sisälsi mahdollisuuden myös oppiaineiden ja tutkinto-ohjelmien harkittuihin lakkauttamisiin. Lisäksi raportissa esitettiin kandidaatti- ja maisteritason rakenteellista erottamista siten, että kandidaatin tutkintoa suorittaville opintooikeutta ei enää myönnettäisi automaattisesti saman yliopiston maisteriopintoihin. Tavoitteena oli lisätä opiskelijoiden liikkuvuutta, yliopistojen välistä kilpailua ja niiden kannustimia keskittyä vahvuusalueilleen ja mahdollisesti profiloitua erikseen kandidaatti- ja maisteriohjelmiin.

Paljosta puheesta ja kovasta järjestelmätason tahtotilasta huolimatta profiloitumista ei ole juurikaan yliopistojen välillä tapahtunut. Yliopistot ovat ymmärrettävästi olleet varovaisia tekemään toimenpiteitä, jotka merkitsisivät koulutusalojen lakkauttamista tai siirtoa toiseen yliopistoon. Painopistevalinnat kuuluvat tieteen autonomian ja akateemisen työn ytimeen ja ovat siksi yliopistoille vaikeasti ratkaistava johtamishaaste. Yliopistolähtöinen profiloituminen nimittäin tosiasiallisesti edellyttää oppiaine- ja tieteenalatoimijoiden (henkilökunta, opiskelijat, sidosryhmät) riittävää kannatusta tai vähintäänkin hiljaista hyväksyntää.

Samalla yliopistoille esitettyjen profiloitumisvaateiden kannalta on ongelmallista, että opetus- ja kulttuuriministeriöllä (OKM) itsellään ei ole selkeää kriteeristöä "riittävän" yliopistokohtaisen profiloitumisen määrittelemiseksi. OKM:lle tuntuu olevan suunnan ja päämäärän sijasta tärkeämpää itse liike. Eräänä syynä profiloitumishalukkuuden puutteeseen 
voidaan pitää myös yliopistojen perusrahoitusmallia, joka ei ole viimeaikaisten selvitysten mukaan kannustanut sen paremmin yliopistojen yhteistyöhön kuin merkittäviin profiloitumistoimiin. Vuonna 2018 Talouspolitiikan arviointineuvoston julkaiseman raportin "Yliopistojen rahoitus, kannustimet ja rakennekehitys" mukaan tieteenaloittainen hajaantuneisuus on yliopistoissa pikemminkin lisääntynyt kuin vähentynyt (Seuri \& Vartiainen 2018, 32).

Oma asiansa on tietenkin koko profiloitumisen tavoiteltavuus. Profiloitumista koskevassa tavoitteenasetannassa on tärkeää ymmärtää, että tutkimuksen ja koulutuksen profiloitumisen lähtökohdat ovat monella tapaa erilaisia. Koulutuksen osalta painottuvat työmarkkinoihin ja alueellisiin tarpeisiin liittyvät tekijät tutkimusta enemmän. Tutkimuksen osalta tärkeää on riittävän laajapohjaiset tutkimusryhmät. Tutkimusympäristöjen vetovoimaisuuden ja näkyvyyden näkökulmasta suuremmat, yhteen paikkaan kootut keskittymät saattavat olla tavoiteltava tila, mutta sama logiikka ei välttämättä päde koulutustoiminnassa. Ylipäätään suurempien yksikkökokojen ja mittakaavaetujen aikaansaamista tuottavuushyödyistä ei ole selvää tutkimukseen perustuvaa näyttöä, etenkään kun usein samat hyödyt ovat saavutettavissa usean toimijan verkostoyhteistyöllä.

Kansallinen koulutuksen arviointikeskus (KARVI) julkisti 23.1.2020 vuoden 2019 aikana toteutettujen neljän koulutusalan (humanistisen alan, kauppatieteiden ja liiketalouden, tekniikan ja yhteiskuntatieteiden) arvioinnit. Osallistuin mainittuihin arviointeihin toimimalla yhteiskuntatieteellisen arviointiryhmän jäsenenä ja puheenjohtajana. Arvioinnin yksi keskeisistä suosituksista liittyy profiloitumisen ymmärtämiseen korkeakoulujen yhteistyötä koskevalla tavalla. Suositustemme mukaan alakohtaista koordinointia ja yhteistyötä yliopistojen välillä tulee lisätä ja kehittää opiskelijavalintojen, opetussuunnitelmien ja tutkintorakenteiden osalta. Opetus- ja viestintäteknologian digitalisoituminen on jo vuosia mahdollistanut kurssimuotoisen etäopiskelun tavalla, joka ei merkittävästi eroa massaluentojen kontaktiopetuksesta. Yhdessä sovittu työnjako moduulien ja kurssien tarjonnassa purkaa päällekkäisyyksiä ja tehostaa toimintaa, vapauttaen näin resursseja etenkin tutkimukseen. Tällainen työnjakoon ja yhteistyöhön kiinnittynyt "mikroprofiloituminen" saa voimansa kaikkia hyödyttävästä yhteistyöstä, ei kilpailusta.

Jussi Kivistö, päätoimittaja 